\title{
Christian response amid economic suffering due to the Covid-19 pandemic
}

\section{Sari Saptorini}

Sekolah Tinggi Teologi Baptis Indonesia, Semarang, Jawa Tengah sarisaptorini@stbi.ac.id

\begin{tabular}{|c|c|}
\hline $\begin{array}{l}\text { Article History } \\
\text { Submitted: } \\
\text { January, } 02,2021 \\
\text { Revised: } \\
\text { February, 23, } 2021 \\
\text { Accepted: } \\
\text { April, } 01,2021\end{array}$ & $\begin{array}{l}\text { Abstract: The Covid- } 19 \text { pandemic has caused suffering not only in the health } \\
\text { sector but also in the economic sector. Christians are also not spared from this } \\
\text { economic suffering. The purpose of this article is to find out how Christians } \\
\text { should respond amid the economic suffering caused by the Covid-19 Pandemic. } \\
\text { This research used a qualitative method and based on library research to find } \\
\text { out the response of Christians amid economic suffering in Acts 11:27-30 and }\end{array}$ \\
\hline $\begin{array}{l}\text { Keywords: } \\
\text { Christian } \\
\text { response; } \\
\text { Covid-19 } \\
\text { pandemic; } \\
\text { economic } \\
\text { suffering }\end{array}$ & $\begin{array}{l}\text { suffering caused by the ongoing Covid- } 19 \text { pandemic. The conclusion drawn } \\
\text { from this study is that Christians should have faith in God who sustains their } \\
\text { lives during the pandemic and take actions that are in line with their faith. The } \\
\text { prosperous Christians should be willing and ready to bless the other Christians } \\
\text { who are suffering more. Likewise, in economic decline, Christians respond by } \\
\text { trusting in God's providence and humbly receiving God's blessings through the } \\
\text { gifts of brothers and sisters who love them. Christians need to with the } \\
\text { government in dealing with this economic suffering until the Covid-19 } \\
\text { pandemic ends. }\end{array}$ \\
\hline
\end{tabular}

\section{Introduction}

In early 2020, the Covid-19 pandemic hit the world and resulted in human suffering almost worldwide. The negative impact of this pandemic is not only in the health sector but has spread to all areas of human life. According to the World Health Organization (WHO), the Covid-19 pandemic has caused dramatic deaths worldwide. On 1 February 2021, WHO received reports that globally, there were 102.399 .513 confirmed cases of Covid-19, including 2.217.005 deaths. ${ }^{1}$ In addition to its negative health impacts, the Covid-19 pandemic has caused a devastating economic and social disruption. Tens of millions of people are at risk of falling into extreme poverty. The number of malnourished people, currently estimated at nearly 690 million, could increase to 132 million at the end of this year. In the workplace, millions of companies face the threat of its existence, and nearly half of the world's 3,3 billion workforces is at risk of losing their livelihoods. ${ }^{2}$ The news about the Covid-19 vaccine is still confusing. WHO states that more than 100 potential Covid-19 vaccines are being developed,

\footnotetext{
${ }^{1}$ WHO, "Weekly Operational Update on COVID-19 - 1 February 2021," WHO, February 2021, https://www.who.int/publications/m/item/weekly-operational-update-on-covid-19---1-february-2021.

${ }^{2}$ Kimberly Chriscaden, Impact of COVID-19 on People's Livelihoods, Their Health and Our Food Systems, 2020, https://www.who.int/news/item/13-10-2020-impact-of-covid-19-on-people's-livelihoods-theirhealth-and-our-food-systems.
} 
and some of them are in the human trial phase. ${ }^{3}$ People do not have certainty about the existence of the vaccine, yet their economic situation has not shown any signs of recovery. People still do not know when this economic suffering will end.

Concerning the impact of the Covid-19 pandemic on the economy, Wibowo Hadiwardoyo's research entitled National Economic Losses Due to the Covid-19 Pandemic, national, sectoral, corporate, and individual economic losses experienced during this pandemic in Indonesia. ${ }^{4}$ Besides, research conducted by Fakrul Rozi Yamali and Ririn Noviyanti Putri shows the impact on the financial sector due to the Covid-19 pandemic in Indonesia, including layoffs, decreased imports, inflation, and losses in the tourism sector due to a decrease in the number of visitors. Meanwhile, concerning the attitudes of Christians and churches during the Covid-19 pandemic, researches have also been conducted. Based on the research conducted, the church has responded to calls from WHO and the government to implement health protocols by implementing worship in homes or by online services broadcast via electronic media that the congregation can access. ${ }^{5}$ A study in Poland shows that Polish churches are changing religious life organizations, and churches maintain contact with believers in various ways, using modern technology and access to public media, for that matter. ${ }^{6}$ The churches need to build spiritual and psychological supporting structures to serve people's mental health during a public health crisis due to the Covid-19 pandemic. ${ }^{7}$ Based on those researches, the author found that there were things that have not been studied yet. One of them is the Christian response amid economic suffering due to the Covid-19 pandemic. Therefore, this article will research and discuss the topic.

Acts 11:27-28 records economic suffering faced by the Christians in Judea during the reign of Claudius. Gapp writes that Josephus records the great famine in Judea, which occurred during the governor of Tiberius Alexander, namely, in 46 or 47 . The famine was so severe that many people were dying because they did not have money to buy food, and the price of groceries and distribution costs rose so high. The famine did not only occur in Judea territory but spread to areas outside Judea. ${ }^{8}$ Furthermore, Acts 11:29-30 speaks of the disciples' response at Antioch to the prophecy. They decided to collect donations according to their abilities and send them to the Christians living in Judea with Barnabas and Saul. From this incident, the disciples showed their resilience in responding to the coming suffering.

The suffering in the economic sector due to the Covid-19 pandemic affects all people from various strata and groups in society, including Christians as children of God in Christ.

\footnotetext{
${ }^{3}$ WHO, The Push for a COVID-19 Vaccine, 2020, https://www.who.int/emergencies/diseases/novelcoronavirus-2019/covid-19-vaccines.

${ }^{4}$ Fakhrul Rozi Yamali and Ririn Noviyanti Putri, "Dampak Pandemi Covid-19 Terhadap Ekonomi Indonesia," Ekonomis: Journal of Economics and Business 4, no. 2 (2020): 384-388.

${ }^{5}$ Roedy Silitonga, "Respon Gereja Atas Pandemik Corona Virus Desease 2019 Dan Ibadah Di Rumah," Manna Rafflesia 6, no. 2 (2020): 86-111.

${ }^{6}$ Lukasz Sulkowski and Grzegorz Ignatowski, "Impact of COVID-19 Pandemic on Organization of Religious Behaviour in Different Christian Denominations in Poland,” Religions 11, no. 5 (2020): 254.

${ }^{7}$ Fides A. del Castillo, Hazel T. Biana, and Jeremiah Joven B. Joaquin, "Correspondence Churchinaction: The Role of Religious Interventions in Times of COVID-19," Journal of Public Health (United Kingdom) 42 , no. 3 (2020): 633-634.

${ }^{8}$ Kenneth Sperber Gapp, “The Universal Famine under Claudius," The Harvard Theological Review 28 (1935): 258--265, https://www.jstor.org/stable/1508135?seq=1.
} 
Christians live on the same earth, so whatever events happen in this world, they also experience it. Therefore, based on the background above, this study aims to describe the response of Christians amid economic suffering in Acts 11:27-30 and confirm the implications for Christians today in responding to the economic suffering caused by the ongoing Covid-19 pandemic.

\section{Research Method}

This study uses a descriptive qualitative method. The researcher chose this method because the qualitative approach was deemed suitable for this topic whose truth was relative, hermeneutical, and interpretive. ${ }^{9}$ This research is also based on library research. The primary material of this research is literature data, both from books and journals, as well as data obtained from news articles on internet links. By using this method, this research will firstly describe the economic suffering as a result of the Covid-19 pandemic, secondly exegete the economic suffering as a result of the famine in the Bible, and then specifically highlight the economic suffering experienced by the disciples as a result of the Judean famine in the Acts 11:27-30. Finally, it produces the implication for Christians today who are experiencing economic suffering due to the Covid-19 pandemic.

\section{Discussion}

\section{Economic Suffering Due to the Covid-19 Pandemic}

The Covid-19 pandemic has a massive impact on the global economy and financial markets. Significant economic suffering occurs worldwide due to reduced productivity, deaths, business closures, trade disruptions, and the collapse of the tourism industry. ${ }^{10}$ The World Bank predicts that the Covid-19 pandemic will plunge most countries into a recession by 2020 , with per capita income shrinking in most countries globally since 1870. Advanced economies are projected to shrink by 7 percent. That weakness will extend to the prospects for emerging markets and developing economies, which are forecast to contract by 2,5 percent as they cope with the domestic virus outbreak on their own. ${ }^{11}$

Meanwhile, quoted from the BBC News website, the economic impact of this pandemic includes, among others, the continuous change in global stocks, an increase in unemployment, the furloughing of millions of workers, the risk of a recession. ${ }^{12}$ In Indonesia, Minister of Finance Sri Mulyani said that there are three impacts of the Covid-19 pandemic on Indonesia's economy: a fall in people's purchasing power, weakening investment, and the cessation of Indonesian exports to several countries. ${ }^{13}$ When breadwinners experience a loss

${ }^{9}$ Sonny Eli Zaluchu, "Strategi Penelitian Kualitatif Dan Kuantitatif Di Dalam Penelitian Agama," Evangelikal 4, no. 1 (2020): 28-38.

${ }^{10}$ Anton Pak et al., "Economic Consequences of the COVID-19 Outbreak: The Need for Epidemic Preparedness," last modified 2020, https://www.frontiersin.org/articles/10.3389/fpubh.2020.00241/full.

${ }^{11}$ The World Bank, "The Global Economic Outlook During the COVID-19 Pandemic: A Changed World," last modified 2020, https:/www.worldbank.org/en/news/feature/2020/06/08/the-global-economicoutlook-during-the-covid-19-pandemic-a-changed-world.

12 Lora Jones, Daniele Palumbo, and David Brown, "Coronavirus: A Visual Guide to the Economic Impact," last modified 2020, https://www.bbc.com/news/business-51706225.

${ }^{13}$ Liputan6.com, "Sri Mulyani: Corona Beri 3 Dampak Besar Ke Ekonomi Indonesia," last modified 2020, https://www.liputan6.com/bisnis/read/4292763/sri-mulyani-corona-beri-3-dampak-besar-ke-ekonomiindonesia. 
of income, they may use negative coping strategies, such as selling assets they own, borrowing from moneylenders, or employing their children. Worse still, when the breadwinner loses his job, gets sick, and dies, it will affect the food safety and nutrition of the family. The Covid-19 pandemic has also affected the entire food system. Closing borders, trade restrictions, and confinement measures have prevented farmers from accessing markets, including buying raw materials and sell their produce. Agricultural workers are having trouble harvesting the products of their land, disrupting domestic and international food supply chains, and reducing access to healthy, safe, and diverse food. ${ }^{14}$ If there is no solution immediately, then the worst thing that is worried about happening is a famine in various regions, especially in impoverished countries. Although people receive the vaccine, it is not easy to revive the country's economy hit by a recession.

\section{Economic Suffering and the Christian Response in Acts 11: 27-30}

Acts 11:27-30 reports the arrival of the prophet Agabus from Jerusalem to Antioch foretold a great famine in the land of Judea during the reign of Claudius Caesar. Claudius reigned from 41-54 AD, and the famine hit Judea and all parts of the eastern Mediterranean in $46 \mathrm{AD} .{ }^{15}$ The famine lasted more than three years and had an impact on the lives of the new believers in Judea as well. ${ }^{16}$ The Christian Jews in the Jerusalem church experienced severe economic suffering due to the famine. They became poor and lack. Many people were in distress because they could not meet their needs. ${ }^{17}$ Josephus mentions in his narrative that the famine occurred during the reign of Claudius Caesar. The famine was severe, while the Roman empire was unable or unwilling to distribute food supplies to all its territories, including Judea. Even in Jerusalem, many people perished as a result of having no money. Help for the people of Jerusalem came from Queen Helena of Adiabene and her son, Izates, who had decided to embrace Judaism. Whenever Queen Helena came to worship at the Temple in Jerusalem, she distributed provisions to the needy. Izates also sent money for famine relief. ${ }^{18}$

The Christians in Antioch learned about the famine from the prophecy of Agabus. They believed that Agabus was a prophet of God and accepted his words. This belief has made them collect donations for the Christian brothers in Judea in anticipation of the economic suffering. ${ }^{19}$ They collected money voluntarily and according to their respective abilities (Acts 11:29). Although there are chronological problems, there are two fundamental problems shown in their actions: first, severe food shortages in Judea under Claudius. Second, neither Caesar nor the local Roman authorities did anything about it because considered outside the responsibilities of the Roman government. ${ }^{20}$

Josephus says nothing about the donations from the Christians in Antioch, but Paul's letters show that the collection for the church in Jerusalem was important. During Paul's third

\footnotetext{
${ }^{14}$ Chriscaden, Impact of COVID-19 on People's Livelihoods, Their Health and Our Food Systems.

${ }^{15}$ Randal S. Chase, New Testament Study Guide, Pt. 2: The Infinite Atonement / Acts of the Apostles (Washington: Plain \& Precious Publishing, 2010).

${ }^{16}$ Chriscaden, Impact of COVID-19 on People's Livelihoods, Their Health and Our Food Systems.

17 Ibid.

${ }^{18}$ Josiah Osgood, Claudius Caesar: Image and Power in The Early Roman Empire (New York: Cambridge University Press, 2011), 131-132.

${ }^{19}$ Forest L Sr, Walker, The Prophetic Perfect (Xlibris Corporation, n.d.), 52.

${ }^{20}$ Osgood, Claudius Caesar: Image and Power in The Early Roman Empire.
} 
missionary journey, he also traveled to Jerusalem to deliver donations from Greek Christians for the poor Jewish Christians due to famine in Jerusalem. Paul knew that there were still Jews who objected to these Greek Christians but that donation would open opportunities for acceptance that all people are equal in Christ. ${ }^{21}$

In his letter to Rome, Paul wrote that the Macedonian and Achaia churches made their contributions willingly and not under compulsion (Rom. 15:26). However, not all churches did the same. Paul had to explain to the Corinthians how the donation collection worked for the church in Jerusalem who was experiencing economic suffering. Paul wrote in both his letters to the Corinthians. First, in 1 Corinthians 16:1-4, Paul said that he had given instructions regarding the collection of money for the Jerusalem church, that the church should give according to their ability and readily. Paul was glad that Gentile Christians had the opportunity to be a blessing to Jewish Christians in need and be in unity. Second, in 2 Corinthians 9:1-6, Paul reminded them of their readiness and willingness. Paul and his associates had decided to donate all the collected money only for the famine relief in Jerusalem and not for any other purposes. ${ }^{22}$

From the description above, two things concluded as the response of Christians in facing the economic suffering due to famine at that time, namely: faith and action. First, they had faith in God, who had revealed to His prophet the coming famine. They had faith in what the prophet of God said is true and will happen. They believed that famine would strike and trusted God would sustain their lives during this famine. The Bible does not record their reactions after hearing this prophecy, but their decision to collect donations for Christians in Judea demonstrated their faith in God's provision. Their ability to make donations proved God's provision in sustaining their lives. Second, they acted according to their faith. When famine hit, it was inevitable that God's people would also be affected by economic suffering. This economic suffering may occur over a long period. It took them more than once to raise money to help Christian brothers who became poor and hungry. This action required willingness and graciousness. They would not be able to give in continuity if they were concerned that they would end up experiencing the same economic suffering. Apart from being willing, they must also show readiness to give. That readiness showed that they cared for their suffered brothers. They thought about and shared in the suffering by placing aside what they must donate. The rich did not seek prosperity for themselves but were willing to be a blessing to those in need. The collection of money was carried out by one local church, but several churches jointly carried out loving ministry by entrusting the money to Paul and his friends to be delivered to the needy.

What about the response of the congregation in Jerusalem who experienced economic suffering immediately due to the famine? They must also put their faith in God, who will keep them alive. The Bible records various ways in which God cares for his people. In this episode, God used Greek Christians to help Jewish Christians in Jerusalem. In this way, God was creating unity in His people. Besides having faith, they must also act, that is, accept this

${ }^{21}$ Twyman Preston Joyner, His Mighty Word of Power: A Theological Apologetic Bible Study Aid (Bloomington: WestBow Press, 2012), 166.

22 Joyner, His Mighty Word of Power: A Theological Apologetic Bible Study Aid. 
assistance humbly. The Jewish Christians had to destroy their pride as Jews to receive help from the Gentiles. They no longer thought that their nation is more superior to others. Paul as a man who God had called to serve the Gentiles and entrusted by the church to deliver the donations to the poor church in Jerusalem, had fully understood that before God, there was no difference between the Jews and the Greeks in Jerusalem in Christ (Rom. 10:12; 1Cor. 12:13; Gal. 3:28; Col. 3:11).

\section{Implications for Christian Responses Amid Economic Suffering Due to the Covid-19}

Amid the economic suffering caused by the Covid-19 Pandemic, Christians should firstly respond by having faith in God. Christians need to put their trust in God, who foreknew this pandemic. The God who has previously cared for His people during times of economic suffering as narrated in the Bible is the same God who will continue to care for His people today amid the economic suffering caused by the Covid-19 pandemic. Christians need to believe every promise of God's providence.

However, the Christian faith is not passive. God wants Christians to show their dedication through their works. How to manifest works based on faith can be seen from the story of Christians who were facing economic suffering due to famine in Acts 11:27-30. There, God cares for both parties, the blessing Christians and suffering Christians. God gave such help to the Gentile churches to set aside money to help the poor Jerusalem church without making them broke. And God blessed the economically suffering church in Jerusalem through the donations of other believers. This story gives comfort and encouragement for Christians today to act in responding to economic suffering.

Christians who can still survive the pandemic and have more blessings should be encouraged to bless their Christian brothers experiencing more economic suffering due to this pandemic. The government and social institutions have also assisted people affected by the pandemic. Some of the programs launched by the government to meet people's needs include social assistance in the form of necessities, cash, and a pre-employment card program. ${ }^{23}$ It would be good for the church to go along with the government's agenda as a charitable plan. Besides, the church must obey the government policy about implementing the 'new normal' in responding to the Covid-19 pandemic. ${ }^{24}$ Religious communities directly impact the spread of the virus either by inhibiting or accelerating social transmission. It happened with the emergence of clusters of worship places. People who carry out religious activities gather and interact with each other without implementing health protocols. ${ }^{25}$ The primary prevention strategy is to practice social distancing. Large numbers of people gathering and doing religious activities provide fertile ground for the spreading of new pathogens. If the church refuses to postpone such gatherings, the potential for widespread infection will increase. ${ }^{26} \mathrm{By}$

\footnotetext{
${ }^{23}$ Sekretaris Kabinet Republik Indonesia, "Pemerintah Berikan 6 Program Bantuan Tambahan Hadapi Pandemi Covid-19," Sekretaris Kabinet Republik Indonesia (Jakarta, April 2020), https://setkab.go.id/pemerintah-berikan-6-program-bantuan-tambahan-hadapi-pandemi-covid-19/.

${ }^{24}$ Jerry Pillay, "COVID-19 Shows the Need to Make Church More Flexible," Transformation 37, no. 4 (2020): 266-275.

${ }^{25}$ Wesley J Wildman et al., "Religion and the COVID-19 Pandemic" 5981 (2020): 115-117.

${ }^{26}$ Sayed A. Quadri, "COVID-19 and Religious Congregations: Implications for Spread of Novel Pathogens," International Journal of Infectious Diseases 96 (2020): 219-221, https://doi.org/10.1016/j.ijid.2020.05.007.
} 
obeying the government, Christians prove their love and concern for fellow members of the body of Christ.

Local churches must be willing to unite and support one another in this ministry of love. A heavy burden borne together will be light. In its application, during this pandemic, the assistance is not always in the form of money. It can be in the form of food, job opportunities, temporary shelter, means of transportation to deliver food, time to pray, hospitality and encouragement, and so on. The church also can give training programs to equip people to face the improvement of technology. The church can use technology to deliver God's Word online to strengthen the faith. Besides, technology is beneficial in the business sector to help the economic revival of church members who suffer economically. Christians should give voluntarily and readily. The Word of God comforts His people that God will continue to provide what they need. God, who provides seed for the sower, and bread to eat, will also multiply the seed for generous Christians and increase the fruit of their righteousness (2Cor. 9:10).

Meanwhile, Christians whose economic conditions have worsened due to this pandemic must also continue to believe that God will never be too late in providing His help. They must not limit God's way of delivering them from their suffering. They must be willing to humble themselves in accepting aid from others. This action does not mean that they rely solely on humans, but they recognize God as the source of all blessing. They should be grateful for God's blessings, which are material and the love, care, and support of their Christian brothers. When love and humility meet, they create unity in the body of Christ.

\section{Conclusion}

The Covid-19 pandemic is bringing economic suffering to people around the world. This suffering also afflicts Christians. The proper response to the economic suffering caused by the Covid-19 pandemic is to trust in God's care and bless their brothers and sisters in Christ who are suffering more. Likewise, Christians in an economic slump respond by trusting in God's providence and humbly receiving God's blessings through the gifts of brothers and sisters who love them. Christians need to unite and work together with the government in dealing with this economic suffering until the Covid-19 pandemic ends.

This research can serve as a discourse on the importance of caring for and loving people who experience economic suffering to defend their lives amid the Covid-19 pandemic and to create commonweal in the community. Furthermore, this research is a discourse on the importance of the local churches' unity and cooperation. The churches serve as tools of God and the government during the time of the pandemic. Researchers recommend further research on (1) the churches' roles in saving the congregations and communities around the churches from economic suffering due to the Covid-19 pandemic; (2) the influence of economic suffering experienced on the spirituality of the church members; (3) the effect of the economic suffering experienced on the tithe and offerings given by the members to the church. 


\section{References}

del Castillo, Fides A., Hazel T. Biana, and Jeremiah Joven B. Joaquin. "Correspondence Churchinaction: The Role of Religious Interventions in Times of COVID-19." Journal of Public Health (United Kingdom) 42, no. 3 (2020): 633-634.

Chase, Randal S. New Testament Study Guide, Pt. 2: The Infinite Atonement / Acts of the Apostles. Washington: Plain \& Precious Publishing, 2010.

Chriscaden, Kimberly. Impact of COVID-19 on People's Livelihoods, Their Health, and Our Food Systems, 2020. https://www.who.int/news/item/13-10-2020-impact-of-covid-19on-people's-livelihoods-their-health-and-our-food-systems.

Gapp, Kenneth Sperber. "The Universal Famine under Claudius." The Harvard Theological Review 28 (1935): 258--265. https://www.jstor.org/stable/1508135?seq=1.

Indonesia, Sekretaris Kabinet Republik. "Pemerintah Berikan 6 Program Bantuan Tambahan Hadapi Pandemi Covid-19.” Sekretaris Kabinet Republik Indonesia. Jakarta, April 2020. https://setkab.go.id/pemerintah-berikan-6-program-bantuan-tambahan-hadapipandemi-covid-19/.

Jones, Lora, Daniele Palumbo, and David Brown. "Coronavirus: A Visual Guide to the Economic Impact." Last modified 2020. https://www.bbc.com/news/business51706225.

Joyner, Twyman Preston. His Mighty Word of Power: A Theological Apologetic Bible Study Aid. Bloomington: WestBow Press, 2012.

Liputan6.com. "Sri Mulyani: Corona Beri 3 Dampak Besar Ke Ekonomi Indonesia." Last modified 2020. https://www.liputan6.com/bisnis/read/4292763/sri-mulyani-coronaberi-3-dampak-besar-ke-ekonomi-indonesia.

Osgood, Josiah. Claudius Caesar: Image and Power in The Early Roman Empire. New York: Cambridge University Press, 2011.

Pak, Anton, Oyelola Adegboye, Adeshina Adekunle, Kazi Rahman, Emma McBryde, and Damon Eisen. "Economic Consequences of the COVID-19 Outbreak: The Need for Epidemic Preparedness." Last modified 2020. https://www.frontiersin.org/articles/10.3389/fpubh.2020.00241/full.

Pillay, Jerry. "COVID-19 Shows the Need to Make Church More Flexible." Transformation 37, no. 4 (2020): 266-275.

Quadri, Sayed A. "COVID-19 and Religious Congregations: Implications for Spread of Novel Pathogens." International Journal of Infectious Diseases 96 (2020): 219-221. https://doi.org/10.1016/j.ijid.2020.05.007.

Silitonga, Roedy. "Respon Gereja Atas Pandemik Corona Virus Desease 2019 Dan Ibadah Di Rumah.” Manna Rafflesia 6, no. 2 (2020): 86-111.

Sr, Walker, Forest L. The Prophetic Perfect. Xlibris Corporation, n.d.

Sulkowski, Lukasz, and Grzegorz Ignatowski. "Impact of COVID-19 Pandemic on Organization of Religious Behaviour in Different Christian Denominations in Poland." Religions 11, no. 5 (2020): 1-15.

The World Bank. "The Global Economic Outlook During the COVID-19 Pandemic: A Changed World." Last modified 2020. https://www.worldbank.org/en/news/feature/2020/06/08/the-global-economic-outlookduring-the-covid-19-pandemic-a-changed-world.

WHO. The Push for a COVID-19 Vaccine, 2020. https://www.who.int/emergencies/diseases/novel-coronavirus-2019/covid-19-vaccines. . "Weekly Operational Update on COVID-19 - 1 February 2021." WHO, February 2021. https://www.who.int/publications/m/item/weekly-operational-update-on-covid19---1-february-2021. 
Wildman, Wesley J, Joseph Bulbulia, Richard Sosis, Uffe Schjoedt, Wesley J Wildman, Joseph Bulbulia, Richard Sosis, and Uffe Schjoedt. "Religion and the COVID-19 Pandemic" 5981 (2020): 1-4.

Yamali, Fakhrul Rozi, and Ririn Noviyanti Putri. "Dampak Pandemi Covid-19 Terhadap Ekonomi Indonesia." Ekonomis: Journal of Economics and Business 4, no. 2 (2020): 384-388.

Zaluchu, Sonny Eli. "Strategi Penelitian Kualitatif Dan Kuantitatif Di Dalam Penelitian Agama." Evangelikal 4, no. 1 (2020): 28-38. 